Огляди літератури, оригінальні дослідження, погляд на проблему, випадок з практики, короткі повідомлення УДК 616.231-072.1:616.006.03

DOI 10.11603/1811-2471.2020.v.i3.11593

\title{
КЛІНІЧНИЙ ВИПАДОК ЕНДОСКОПІЧНОГО ВИДАЛЕННЯ ФІБРОМИ ТРАХЁ̈
}

\author{
๑В. В. Мальований, Л. Є. Війтович, М. В. Саноцька
}

Тернопільський національний медичний університет імені І. Я. Горбачевського МОЗ України

РЕЗЮМЕ. Частота первинних пухлин трахеї становить менше ніж 0,1%. Нерідко їх неправильно діагностують як астму або хронічне захворювання легень, що відстрочує лікування на місяці або роки.

Як клінічний приклад можна розглянути випадок фіброми трахеї з нашої практики. Пацієнтка, 40 років, була направлена у відділення пульмонології КНП «Тернопільська університетська лікарня» ТОР з діагнозом тяжкої рефрактерної бронхіальної астми. Незважаючи на інтенсивне протиастматичне лікування, показники спірометрії поступово погіршувалися. Для уточнення діагнозу пацієнтці проведена комп'ютерна томографія органів грудної клітки та виявлено пухлиноподібний утвір у просвіті трахеї. Хвору з діагнозом пухлини трахеї терміново направили у відділення торакальної хірургії для подальшої діагностики та лікування. Хірургічне лікування проводили з використанням гнучкого фібробронхоскопа під місцевою анестезією. Ендоскопічну діатермічну петлю через канал бронхоскопа накидали на основу пухлини. Для відсікання застосовували електрохірургічний апарат Olympus UES-30 в послідовному режимі коагуляції 30 Вт і в режимі різання 25 Вт. При цьому пухлина прилипала до ендоскопічної петлі і видалялась разом із бронхоскопом.

Післяопераційний перебіг без ускладнень, протягом періоду спостереження нападів задишки не спостерігалося, нормалізувались показники спірометрії.

Висновки. Невелика частота клінічних випадків новоутворень трахеї у практиці лікаря терапевтичного профілю приводить до низької настороженості відносно даної патології. Труднощі у діагностиці зумовлені малою інформативністю клінічної картини на стадії початкової симптоматики. Вчасне встановлення діагнозу дає можливість провести ендоскопічне втручання, яке приводить до повного одужання пацієнта.

КлючовІ СлОВА: фіброма трахеї; диференційна діагностика; ендоскопічне видалення.

Вступ. Частота первинних пухлин трахеї становить менше ніж 0,1\% [1], однак нерідко вони становлять діагностичні і терапевтичні труднощі. Доброякісні пухлини зазвичай помилково діагностують як астму або хронічне захворювання легень і лікування розтягується на місяці або роки [2]. Спостереження свідчать, що від 12 до 30 \% випадків неконтрольованої астми насправді були неправильно діагностовані. До найпоширеніших захворювань - масок для астми - належать дисфункція голосових зв'язок, чужорідне тіло в дихальних шляхах, порушення кровообігу, бронхоектатична хвороба, алергічний бронхолегеневий аспергільоз, саркоїдоз та легенева гіпертензія.

У дорослих серед доброякісних новоутворень трахеї переважають папіломи, фіброми. Рідше трапляються лейоміома, міобластома, лімфангіома, невринома, хондрома, ліпома [3]. Фіброма $\epsilon$ доброякісним утворенням, що складається зі зрілих клітин, які зберігають функції фібробластів і сполучнотканинних волокон. Коли фіброма має в своєму складі велику кількість кровоносних судин, іï описують під назвою ангіофіброма. Солітарні доброякісні новоутворення різного ґенезу рентгенологічно і ендоскопічно нерідко виглядають а6солютно однаково, як округлі гладкі рожеві утворення на ніжці до 2 см у діаметрі. Провести диференційну діагностику на підставі тільки клінічних даних неможливо, проте іноді поверхня, забарвлення і зовнішній вигляд пухлини можуть дати деякі дані для оцінки нозологічної форми і вирішен- ня питання про можливість ендоскопічного видалення. При багатьох пухлинах їх радикальне або паліативне видалення можливе через бронхоскоп за допомогою ультразвуку, діатермокоагуляції, кріодеструкції, лазерної фотокоагуляції $[4,5]$. При лікуванні доброякісних пухлин ендоскопічні лазерні операції як самостійний метод повинні застосовуватися лише за можливості радикального видалення [4].

Як клінічний приклад можна розглянути такий випадок фіброми трахеї. Пацієнтка, 40 років, була направлена у відділення пульмонології КНП «Тернопільська університетська лікарня" ТОР із діагнозом тяжкої рефрактерної бронхіальної астми. За даними анамнезу, бронхіальна астма діагностована 3 роки тому. Жінка продавець за професією, без інших хронічних захворювань, у сімейному анамнезі бронхіальна астма не прослідковувалась. Домінуючими симптомами були нападоподібна задишка, сухий кашель. Незважаючи на інтенсивне протиастматичне лікування, показники спірометрії поступово погіршувалися. Для уточнення діагнозу пацієнтці проведена комп'ютерна томографія (КТ) органів грудної клітки, в результаті якого виявлено пухлиноподібний утвір у просвіті трахеї (рис. 1, A).

Наступним етапом виконана бронхоскопія. У дистальній частині трахеї приблизно на 4 см вище біфуркації - пухлина діаметром близько 12 мм (рис. 1, Б). Було отримано цитологічний аспірат. Висновок - атипових клітин не виявлено. Хвору 3 
Огляди літератури, оригінальні дослідження, погляд на проблему, випадок з практики, короткі повідомлення
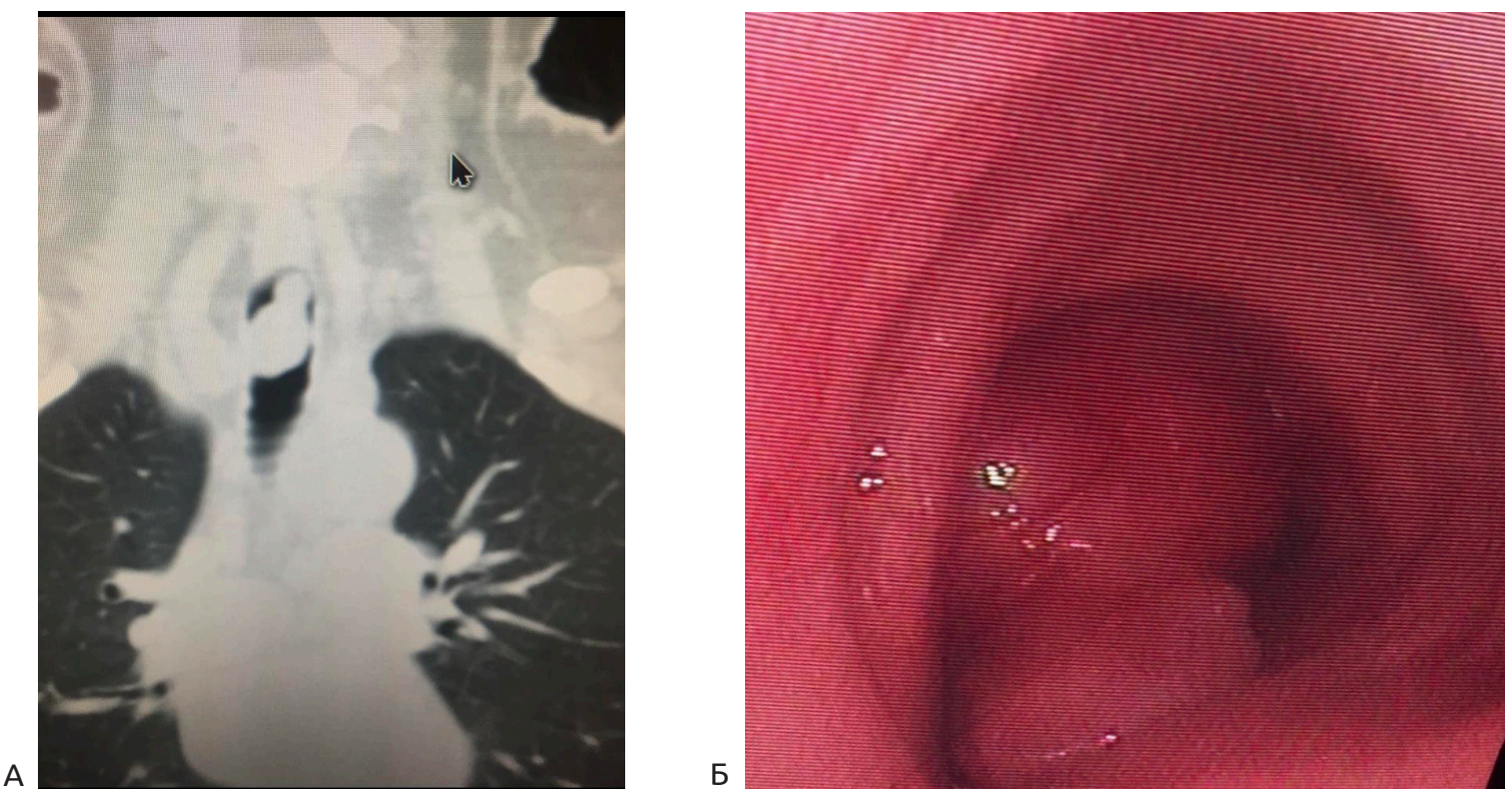

Рис. 1. Пухлиноподібний утвір у просвіті трахеї: А - на скані КТ; Б - при бронхоскопії.

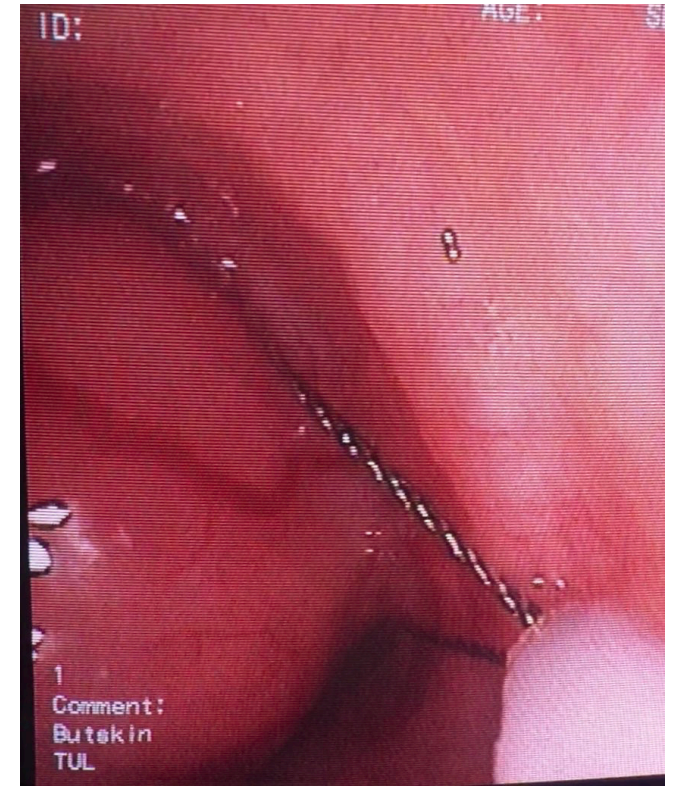

Рис. 2. Ендоскопічне видалення пухлини трахеї.

діагнозом пухлина трахеї, терміново направили у відділення торакальної хірургії для подальшої діаг- ностики та лікування. Хірургічне лікування проводили з використанням гнучкого фібробронхоскопа під місцевою анестезією. Ендоскопічну діатермічну петлю через канал бронхоскопа накидали на основу пухлини. Для відсікання застосовували електрохірургічний апарат Olympus UES-30 у послідовному режимі коагуляції 30 Вт і в режимі різання 25 Вт. При цьому пухлина прилипала до ендоскопічної петлі і видалялась разом із бронхоскопом (рис. 2).

Післяопераційний перебіг був без ускладнень, впродовж періоду спостереження нападів задишки не було, показники спірометрії нормалізувались.

Висновки. 1. Невелика частота клінічних випадків новоутворень трахеї у практиці лікаря терапевтичного профілю призводить до низької настороженості лікарів щодо вказаної патології.

2. Труднощі у діагностиці цього захворювання полягають, насамперед, у малій інформативності клінічної картини на стадії початкової симптоматики.

3. Вчасно встановлений діагноз дає можливість проведести ендоскопічне втручання та привести до повного одужання пацієнта.

\section{ЛІТЕРАТУРА}

1. Ahn Y. Primary tracheal tumors: review of 37 cases / Y. Ahn, H. Chang, Y. S. Lim [et al.] // Thorac. Oncol. - 2009. Vol. 4 (5). - P635-638.

2. Park J. S. Primary leiomyoma of the trachea, bronchus, and pulmonary parenchyma-a single-institutional experience / J. S. Park, M. Lee, H. K. Kim [et al.] // Eur. J. Cardiothorac Surg. - 2012. - Vol. 41 (1). - P. 41-52.

3. Macchiarini P. Primary tracheal tumours/ P Macchi- arini // Lancet Oncol. -2006. - No. 7 (1). - P. 83-91.

4. Sutejda G. Endobronchial electrocautery and argon plasma coagulation / G. Sutejda, C. T. Bolliger // Interventional bronchoscopy. - 2000. - Vol. 4 (15). - P. 2-14.

5. Халак М. Й. Наш опыт диагностики и лечения фибром трахеи / М. Й. Халак, О. М. Мельник // Таврический медико-биологический вестник. - 2011. - № 4 (14). С. 210-212. 
Огляди літератури, оригінальні дослідження, погляд на проблему, випадок з практики, короткі повідомлення REFERENCES

1. Ahn, Y., Chang, N., \& Lim, Y.S. (2009). Primary tracheal tumors: review of 37 cases. Thorac. Oncol., 4 (5), 635-638.

2. Park, J.S., Lee, M., Kim, H.K., Choi, Y.S., Kim, K., \& Kim, J. (2012). Primary leiomyoma of the trachea, bronchus, and pulmonary parenchyma - a single-institutional experience. Eur. J. Cardiothorac. Surg., 41 (1), 41-52.

3. Macchiarini, P. (2006) Primary tracheal tumours. Lancet Oncol., 7 (1), 83-91.
4. Sutejda, G. \& Bolliger, C.T. (2000). Endobronchial electrocautery and argon plasma coagulation. Interventional Bronchoscopy, 4 (15), 2-14.

5. Halak, M.Y., \& Melnik, O.M. (2011). Nash opyt diagnostiki i lecheniya fibrom trahei [Our experience in the diagnosis and treatment of tracheal fibroids]. Tavricheskiy mediko-biologicheskiy vestnik - Tavrichesky Medico-biological Bulletin, 4 (14), 210-212 [in Russian].

\title{
КЛИНИЧЕСКИЙ СЛУЧАЙ ЭНДОСКОПИЧЕСКОГО УДАЛЕНИЯ ФИБРОМЫ ТРАХЕИ
}

\author{
ФВ. В. Малеваный, Л. Е. Вийтович, М. В. Саноцкая
}

Тернопольский национальный медицинский университет имени И. Я. Горбачевского МОз Украины

РЕзЮМЕ. Частота первичных опухолей трахеи составляет менее 0,1%, однако нередко их ошибочно диагностируют как астму или хроническое заболевание легких, что может затягивать лечение на месяцы или годы.

Как клинический пример можно рассмотреть следующий случай фибромы трахеи. Пациентка, 40 лет, была направлена в отделение пульмонологии КНП «Тернопольская университетская больница» ТОР с диагнозом тяжелой рефрактерной бронхиальной астмы. Несмотря на интенсивное противоастматическое лечение, наблюдалось постепенное ухудшение показателей спирометрии. Для уточнения диагноза пациентке проведена компьютерная томография органов грудной клетки и выявлено опухолеподобное образование в просвете трахеи. Больную с диагнозом опухоли трахеи срочно направили в отделение торакальной хирургии для дальнейшей диагностики и лечения. Хирургическое лечение проводилось с использованием гибкого фибробронхоскопа под местной анестезией. Эндоскопическая диатермические петля через канал бронхоскопа набрасывалась на основание опухоли. Для отсечения применяли электрохирургический аппарат Olympus UES-30 в последовательном режиме коагуляции 30 Вт и в режиме резки 25 Вт. При этом опухоль прилипала к эндоскопической петли и удалялась вместе с бронхоскопом.

Послеоперационный период проходил без осложнений, не наблюдалось приступов одышки, нормализовались показатели спирометрии.

Выводы. Небольшая частота клинических случаев новообразований трахеи в практике врача терапевтического профиля приводит к низкой настороженности относительно данной патологии. Трудности в диагностике обусловлены малой информативностью клинической картины на стадии начальной симптоматики. Вовремя установленный диагноз дает возможность провести эндоскопическое вмешательство, что приводит к полному выздоровлению пациента.

КЛючЕВЫЕ СЛОВА: фиброма трахеи; дифференциальная диагностика; эндоскопическое удаление.

\section{CLINICAL CASE OF ENDOSCOPIC REMOVAL OF TRACHEAL FIBROMA ○V. V. Malovanyy, L. E. Viytovych, M. V. Sanotska \\ I. Horbachevsky Ternopil National Medical University}

SUMMARY. The incidence of primary tracheal tumors is less than $0.1 \%$. They are often misdiagnosed as asthma or chronic lung disease and can delay treatment for months or years.

The following case of tracheal fibroma can be considered as a clinical example. The 40-year-old patient was referred to the Pulmonology Department of the Ternopil University Hospital with a diagnosis of severe refractory bronchial asthma. Despite intensive anti-asthmatic treatment, there was a gradual deterioration in spirometry. To clarify the diagnosis, the patient underwent computed tomography of the chest and found a tumor-like formation in the lumen of the trachea. The patient, diagnosed with a tumor of the trachea, was urgently referred to the Department of Thoracic Surgery for further diagnosis and treatment. Surgical treatment was performed using a flexible fibrobronchoscope under local anesthesia. An endoscopic diathermic loop was applied to the base of the tumor through the bronchoscope canal. The Olympus UES-30 electrosurgical apparatus was used for clipping in the serial coagulation mode of $30 \mathrm{~W}$ and in the cutting mode of $25 \mathrm{~W}$. The tumor adhered to the endoscopic loop and was removed together with the bronchoscope.

Postoperative course without complications, during the observation period there were no attacks of shortness of breath, normalized spirometry.

Conclusions. The low frequency of clinical cases of tracheal neoplasms in the practice of a physician of therapeutic profile leads to low vigilance regarding this pathology. Difficulties in diagnosis are due to the low informativeness of the clinical picture at the stage of initial symptoms. Timely diagnosis allows endoscopic intervention and complete recovery of the patient.

KEY WORDS: tracheal fibroma; differential diagnosis; endoscopic removal. 